\title{
Herbage dynamics of tallgrass prairie under short duration grazing
}

\author{
J.E. BRUMMER, R.L. GILLEN, AND F.T. MCCOLLUM
}

\section{Abstract}

Simulated 8-pasture short duration graxing systems were studied in 1985-86 to determine the effect of timing and intensity of grazing on seasonal herbage dynamics. Treatments consisted of 3 grazing schedules $(2,3$, or 4 rotation cycles per 152 day graxing season) and 2 stocking rates (1.3X and 1.8X the recommended normal). Average seasonal standing crop increased from 4-cycle to 2-cycle graxing at the light stocking rate but did not respond to graxing schedule at the heavy stocking rate. Within the grazing season, herbage standing crop was affected by grazing schedule in late summer in 1985 but not in 1986. Favorable growing conditions resulted in light forage utilization which averaged $30 \%$ over all treatments. Net herbage accumulation rates were not affected by any experimental factor and averaged $34 \mathrm{~kg}^{\mathrm{ha}^{-1}} \mathrm{~d}^{-1}$ over all treatments. Time trends for net herbage accumulation rate from May to September were also similar across treatments. Total herbage diasppearance and herbage disappearance per animal-unitday (AUD) were significantly higher under 4-cycle grazing at the heavler stocking rate than under all other treatments.

Key Words: herbage accumulation, herbage disappearance, rotation grazing, stocking rate

Short duration grazing (SDG) is a multi-pasture, one-herd grazing system that involves rapid rotation of livestock. Proper implementation of SDG on rangeland has been reported to allow large increases in stocking rates (Savory 1978).

Stocking rates may be increased if SDG brings about an increase in herbage production (Heitschmidt et al. 1982b). Short duration grazing has been observed to increase herbage production relative to ungrazed areas (Heitschmidt et al. 1982a) and continuous grazing (Jung et al. 1985). Tainton et al. (1977) observed a trend of increased herbage production as the grazing period decreased and the rest period increased. However, Ralphs et al. (1984) found that herbage production was not affected under 4 stocking rates on a SDG system. Because of these inconsistent results, more work is needed on the factors that affect herbage production under SDG before increased stocking rates are advocated based on increased herbage production alone.

Stocking rates can also be increased if SDG increases harvest efficiency by the grazing animal (Heitschmidt et al. 1982b). Harvest efficiency has been shown to increase under SDG as stocking rates increased (Ralphs et al. 1984). Harvest efficiency is directly related to grazing pressure in that as grazing pressure increases, harvest efficiency increases (Stuth et al. 1981, Allison et al. 1982). However, grazing pressure is continuously changing during the growing season and adjustments must be made in stocking rate, stocking density, and/or the length of the grazing period to maintain optimum herbage allowances for increased harvest efficiency (Stuth et al. 1981). Because stocking rates, stocking density, and the length of the graze/rest periods can be adjusted, the grazing pressure in a SDG system can be more precisely controlled than in any other grazing system (Heitschmidt 1984). Thus, increased harvest efficiency is probably the principal factor by which stock-

\footnotetext{
Authors are former graduate research assistant and assistant professor, Agronomy Department, and assistant professor, Animal Science Department, Oklahoma Statc University, Stillwater 74078. Brummer is currently range research coordinator, West Central Research and Extension Center, Route 4, Box 46A, North Platte, Neb. 69101.

Contribution of the Oklahoma Agricultural Experiment Station as Journal Article No. 5174.

Manuscript accepted 1 February 1988.
}

ing rates can be increased under SDG (Heitschmidt et al. 1982b, Walker 1984).

The objective of this study was to determine short-term vegetation responses of tallgrass prairie to short duration grazing. The test hypothesis was that herbage standing crop, net herbage accumulation rate, and herbage disappearance would not be affected by speed of rotation or stocking rate.

\section{Study Area}

The study area was located on the Oklahoma State University Range Research Area approximately $21 \mathrm{~km}$ southwest of Stillwater, Oklahoma. The climate is continental with an average frostfree growing period of 204 days extending from April to October. Average precipitation at Stillwater is $831 \mathrm{~mm}$ with $65 \%$ falling as rain from May to October. Mean temperature is $15^{\circ} \mathrm{C}$ with average minimum and maximum temperatures ranging from $-4.3^{\circ} \mathrm{C}$ in January to $34^{\circ} \mathrm{C}$ in August (Myers 1982).

The soils found on the area are primarily the Grainola and Coyle series, comprising approximately 60 and $35 \%$ of the area, respectively. The Grainola series has a loam surface and silty clay loam subsoil and is a member of the fine, mixed, thermic family of Vertic Haplustalfs. The Coyle series has a fine sandy loam surface and sandy clay loam subsoil and is a member of the fine-loamy, siliceous, thermic family of Udic Argiustolls. Range site classification of the Grainola soil is shallow prairie while the Coyle soil is loamy prairie.

The study area was established in 1984 on native tallgrass prairie. The area was dominated by big bluestem (Andropogon gerardii Vitman), little bluestem (Schizachyrium scoparium (Michx.) Nash), and switchgrass (Panicum virgatum L.), each comprising approximately $18 \%$ of the vegetation by weight in August 1984. Other important species included indiangrass (Sorghastrum nutans (L.) Nash), tall dropseed (Sporobolus asper (Michx.) Kunth), and western ragweed (Ambrosia psilostachya $\mathrm{DC}$.).

\section{Methods}

Three grazing schedule (GRSC) treatments under 2 stocking rates (STRT) were investigated. Grazing schedule treatments were based on the number of complete grazing cycles $(2,3$, or 4$)$ in an 8 pasture rotation that could be completed during a 152-day springsummer grazing season. Within treatments, shorter graze/rest periods were used at the beginning of the grazing season when the vegetation was in a rapid growth stage and were gradually lengthened during the season as the vegetation matured (Table 1). Each

Table 1. Days of grazing and rest per cycle for the 3 grazing schedule treatments.

\begin{tabular}{|c|c|c|c|c|c|c|c|c|c|c|}
\hline \multirow{2}{*}{$\begin{array}{l}\text { Grazing } \\
\text { schedule }\end{array}$} & \multicolumn{2}{|c|}{ Cycle 1} & \multicolumn{2}{|c|}{ Cycle 2 } & \multicolumn{2}{|c|}{ Cycle 3} & \multicolumn{2}{|c|}{ Cycle 4} & \multicolumn{2}{|c|}{ Mean } \\
\hline & $\widehat{\mathbf{D G}^{1}}$ & $\overline{\mathrm{DR}^{2}}$ & $\overline{\mathrm{DG}}$ & $\overline{\mathrm{DR}}$ & $\widehat{\mathrm{DG}}$ & $\overline{\mathrm{DR}}$ & $\overline{\mathrm{DG}}$ & $\overline{\mathrm{DR}}$ & $\overline{\mathrm{DG}}$ & $\overline{\mathrm{DR}}$ \\
\hline 2-cycle & $\begin{array}{l}6 \\
4 \\
3\end{array}$ & $\begin{array}{l}42 \\
28 \\
21\end{array}$ & $\begin{array}{r}13 \\
6 \\
4\end{array}$ & $\begin{array}{l}91 \\
42 \\
28\end{array}$ & $\begin{array}{l}\overline{9} \\
5\end{array}$ & $\begin{array}{l}- \\
63 \\
35\end{array}$ & $\frac{-}{7}$ & $\overline{-}$ & $\begin{array}{r}10 \\
6 \\
5\end{array}$ & $\begin{array}{l}67 \\
44 \\
33\end{array}$ \\
\hline
\end{tabular}

'DG = Days of grazing per cycle.

2DG = Days of rest per cycle. 
treatment pasture received 19 total days of grazing. Grazing began on 1 May and 19 April in 1985 and 1986, respectively. All pastures were burned approximately 2 weeks before the starting dates in both years.

Stocking rate treatments were set at 1.3 (light) and 1.8 (heavy) times the Soil Conservation Service recommended rate for the range sites under study. Three animals were grazed on 0.40 -ha pastures to obtain the light stocking rate while 5 animals were grazed on 0.48 -ha pastures to obtain the heavy stocking rate. Stocker steers and heifers with a starting weight of approximately $275 \mathrm{~kg}$ were used. Stocking rates averaged $110 \mathrm{AUD} \mathrm{ha}^{-1}$ for the light rate and 154 AUD ha $^{-1}$ for the heavy rate.

Treatments were applied using a simulated 8-pasture SDG system. Pasture number 4 in the rotation was used to determine the mean system effect. Grazing treatments were arranged factorially in a randomized complete block design with 3 replications. Each block also contained an ungrazed control pasture 0.20 ha in size.

Total herbage standing crop measurements were taken before and after each grazing period in a given pasture. The before and after sampling dates, however, did not fall on the same dates for all grazing schedule treatments because of differences in the length of the graze/rest periods. To allow direct comparison between treatments, all pastures were sampled on 5 additional dates. These dates were on 1 May, 9 June, 16 July, 22 August, and 28 September in 1985; and 19 April, 29 May, 3 July, 13 August, and 17 September in 1986.

Current year's standing crop, both live and dead, was sampled by clipping $0.1-\mathrm{m}^{2}$ plots to ground level. Fifteen random samples were taken per pasture on each sampling date. In addition, 10 cages were placed in each pasture just prior to a grazing period. At the end of each grazing period, standing crop was sampled under the cages using $0.1 \mathrm{~m}^{2}$ plots. Herbage samples were bagged and dried in a forced-air oven to a constant weight.

Net herbage accumulation rate was calculated for each rest period by subtracting the standing crop at the beginning of the rest period from the standing crop at the end of the rest period and then dividing by the number of days in the period. Net accumulation rates were then weighted by the number of days in the rest period and averaged to arrive at an average net herbage accumulation rate for each treatment.

Herbage disappearance was calculated for each grazing period by subtracting the uncaged standing crop from the caged standing crop at the end of the grazing period. Total herbage disappearance was then calculated for each treatment by summing the disappearance for each grazing period within that treatment. Herbage disappearance was also expressed on an animal-unit-day (AUD) basis by dividing total herbage disappearance by the total number of AUD ha ${ }^{-1}$ for each treatment.

All data were analyzed using analysis of variance techniques for a randomized complete block design with repeated measures. Grazing schedule and stocking rate were whole plot factors while year and sample date were repeated factors. Least significant differences (LSD) for interaction means were calculated with $\alpha=.05$. Statistical procedures followed the methods of Milliken and Johnson (1984).

\section{Results and Discussion}

Precipitation for the period of November 1984 to October 1985 was $51 \%$ above normal. However, July and August rainfall amounts were about average, so that, as normal for this region, a period of unfavorable growth conditions occurred from August to mid-September. November 1985 through September 1986 precipitation was $24 \%$ above average. Precipitation through July was about average but August-September precipitation was over twice normal resulting in excellent late-summer growing conditions.

\section{Herbage Standing Crop}

Grazing schedule and stocking rate interacted to affect average herbage standing crop (Table 2). Standing crop increased as rest
Table 2. Herbage standing crop (kg ha-1, averaged over year and ample date) and net herbaze accumulation rate (kg ha-1 $\mathrm{d}^{-1}$, averaged over year) as affected by the interaction of graxing sehedule and stocking rate.

\begin{tabular}{|c|c|c|c|c|}
\hline \multirow{3}{*}{$\begin{array}{l}\text { Grazing } \\
\text { schedule }\end{array}$} & \multirow{2}{*}{\multicolumn{2}{|c|}{$\frac{\text { Herbage standing crop }}{\text { Stocking rate }}$}} & \multirow{2}{*}{\multicolumn{2}{|c|}{$\begin{array}{c}\text { Accumulation rate } \\
\text { Stocking rate }\end{array}$}} \\
\hline & & & & \\
\hline & Light & Heavy & Light & Heavy \\
\hline $\begin{array}{l}\text { 2-cycle } \\
\text { 3-cycle } \\
\text { 4-cycle } \\
\text { LSD.00 }\end{array}$ & $\begin{array}{l}3490 \\
3230 \\
2980\end{array}$ & $\begin{array}{l}2820 \\
3180 \\
2980\end{array}$ & $\begin{array}{l}35 \\
37 \\
31\end{array}$ & $\begin{array}{l}33 \\
35 \\
35\end{array}$ \\
\hline
\end{tabular}

periods lengthened at the light stocking rate. Standing crop did not respond to grazing schedule at the heavy stocking rate.

Herbage standing crop was affected by the interaction of grazing schedule and sample date in 1985 (Fig. 1). There were no significant differences in standing crop between grazing schedules on any date

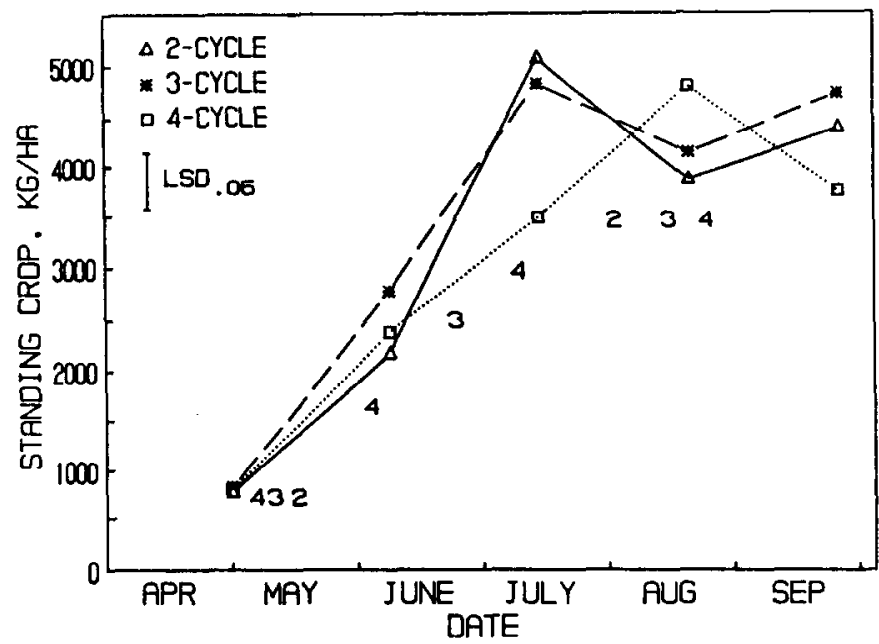

Fi1. 1. Herbage standing crop for 3 grazing schedules in 1985. The LSD refers to grazing schedule comparisons within sample dates. Numbers below graphs indicate the occurrence of grazing periods for the 2,3 , or 4-cycle grazing schedules.

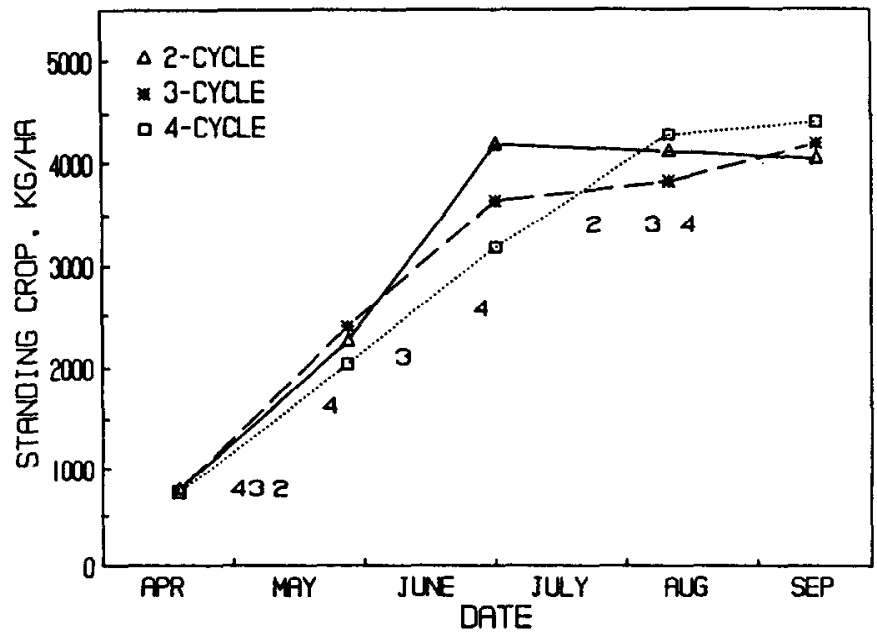

Fig. 2. Herbage standing crop for 3 grazing schedules in 1986. There were no significant differences $(\mathrm{P}=.05)$ between grazing schedules. Numbers below graphs indicate the occurrence of grazing periods for the 2, 3, or 4 cycle grazing schedules. 
in 1986 (Fig. 2). Possible reasons for the different response patterns between years in late summer are not clear but may be related to unfavorable growing conditions during this period in $1985 \mathrm{com}-$ pared to favorable growing conditions in 1986. The occurrence of peak standing crop was delayed in the 4-cycle treatment both years, probably as a result of the more frequent early grazings under this treatment. By the third sample date, the 4-cycle treatment had been grazed 3 times for a total of 12 grazing days. The 2-cycle and 3-cycle treatments had been grazed once for 6 total days and twice for 10 total days, respectively, by the same date. This pattern is not an inherent characteristic of the grazing schedules but is a result of sampling the fourth pasture in an 8 pasture rotation. Grazing schedule will not affect the balance of grazing days between early and late summer when the entire rotation system is considered.

Utilizaton, based on final standing crops in grazed treatments and ungrazed control pastures, was generally low because of above average overall growing conditions in both years. Utilization averaged $30 \%$ over all grazing schedules and $26 \%$ vs. $34 \%$ under light and heavy stocking rates.

\section{Net Herbage Accumulation Rate}

Net herbage accumulation rates (NHAR) were not significantly affected by any experimental factor (Table 2). NHAR averaged 34 $\mathrm{kg} \mathrm{ha}^{-1} \mathrm{~d}^{-1}$ over all grazed treatments and $35 \mathrm{~kg} \mathrm{ha}^{-1} \mathrm{~d}^{-1}$ in ungrazed controls. Trends in NHAR over time were similar among treatments and years. NHAR averaged $60 \mathrm{~kg} \mathrm{ha}^{-1} \mathrm{~d}^{-1}$ in early May and declined linearly to $5 \mathrm{~kg} \mathrm{ha}^{-1} \mathrm{~d}^{-1}$ in late August-early September.

\section{Herbage Disappearance}

Total herbage disappearance was significantly affected by the interaction of grazing schedule and year (Table 3). Differences

Table 3. Total herbage dianppearance (kg ha-1) and herbage diappearance per animal-unit-day (kg AUD-1) as affected by the interaction of grazing schedule and year.

\begin{tabular}{lcccccc}
\hline & \multicolumn{2}{c}{ Total disappearance } & & \multicolumn{2}{c}{ Disappearance per AUD } \\
\cline { 2 - 3 } \cline { 6 - 7 } Grazing & \multicolumn{2}{c}{ Year } & & \multicolumn{3}{c}{ Year } \\
\cline { 2 - 3 } \cline { 5 - 7 } schedule & 1985 & 1986 & & 1985 & 1986 \\
\hline 2-cycle & 1900 & 2370 & & 15 & 18 \\
3-cycle & 2170 & 2310 & & 17 & & 17 \\
4-cycle & 2190 & 3890 & & 16 & & 29 \\
LSD.05 & & 1490 & & & \multicolumn{3}{c}{ NS } \\
\hline
\end{tabular}

were only significant in the 4-cycle treatment in 1986 . We believe these interactions are a product of the 4-cycle, light stocking rate treatment. Total disappearance in this treatment went from 1,070 $\mathrm{kg} \mathrm{ha}^{-1}$ in 1985 to $3,090 \mathrm{~kg} \mathrm{ha}^{-1}$ in 1986 , a $190 \%$ increase. All other treatments increased an average of $23 \%$ from 1985 to 1986 . Evaluation of raw data indicated abnormally low disappearance values for 2 grazing periods in the 4-cycle, light treatment for 1985 which can not be easily explained. Thus, there is an indication of increased herbage disappearance under the 4-cycle grazing schedule. Total herbage disappearance was increased under the heavy stocking rate compared to the light stocking rate $(2,950 \mathrm{vs} .2,000 \mathrm{~kg}$ ha $^{-1}$, respectively; $P=.03$ ).

Results for herbage disappearance per AUD were similar to those for total disappearance (Table 3). The indication of increased herbage disappearance under the 4-cycle grazing schedule is still present. Expressing disappearance on an AUD basis removed the main effect of stocking rate.

Ralphs et al. (1984) reported that total herbage disappearance was similar between stocking rate treatments under simulated SDG. Therefore, as stocking rate increased, disappearance per
AUD decreased and harvest efficiency apparently increased (Ralphs et al. 1984). Allison et al. (1982) found that as grazing pressure went from 50 to $10 \mathrm{~kg}$ of herbage $A \mathrm{AU}^{-1}$ herbage disappearance decreased from 16.3 to $8.5 \mathrm{~kg} \mathrm{AUD}^{-1}$ and harvest efficiency increased from 53 to $99 \%$, respectively. Grazing pressure on this study ranged from $135 \mathrm{~kg} \mathrm{AUD}^{-1}$ on the 4-cycle light treatment to $30 \mathrm{~kg}$ of herbage $\mathrm{AUD}^{-\mathrm{P}}$ on the 2-cycle heavy treatment with an average across all treatments of $70 \mathrm{~kg}$ of herbage $\mathrm{AUD}^{-1}$. Grazing pressures may have been too low for increased stocking rate to affect herbage disappearance $A U D^{-1}$ in this study.

\section{Summary}

Grazing schedule had limited and inconsistent effects on shortterm herbage dynamics of tallgrass prairie. This response pattern may be partly attributed to above-average growing conditions which resulted in relatively low utilization levels. Under seasonal grazing, the observed utilization rates would certainly fall below recommended allowable levels. Under yearlong grazing where herbage must be conserved for dormant-season use, the observed growing-season utilization rates would be closer to recommended levels for moderate grazing. Under the conditions studied, grazing schedule caused differences in herbage standing crop on some sampling dates but average seasonal standing crop only responded to grazing schedule at the lighter stocking rate. Grazing schedule or stocking rate did not affect net herbage accumulation rate. There was some indication that shorter grazing cycles increased herbage disappearance per AUD. However, it is not known if this increased disappearance was a result of greater herbage intake or greater nonconsumptive herbage losses. While higher stocking rates caused greater total herbage disappearance, herbage disappearance per AUD was not generally affected by stocking rate.

\section{Literature Cited}

Allieon, C.D., M.M. Kothmann, and L.R. Rittenhouse. 1982. Efficiency of forage harvest by grazing cattle. J. Range Manage. 35:351-354.

Heitschmidt, R.K., D.L. Price, R.A. Gordon, and J.R. Frasure. 1982 a. Short duration grazing at the Texas Experimental Ranch: effects on above ground net primary production and seasonal growth dynamics. J. Range Manage. 35:367-372.

Heitsehmidt, R.K., J.R. Frasure, D.L. Price, and L.R. Rittenhouse. 1982b. Short duration grazing at the Texas Experiment Ranch: weight gains of growing heifers. J. Range Manage. 35:375-379.

Heituchmidt, R.K. 1984. The ecological efficiency of grazing management, p. 378-385. In: Proc. 1984 Forage and Grassl. Conf., Amer. Forage and Grassland Council.

Jung, H.G., R.W. Rice, and L.J. Koong. 1985. Comparison of heifer weight gains and forage quality for continuous and short-duration grazing systems. J. Range Manage. 38:144-148.

Milliken, G.A., and D.E. Johnson. 1984. Analysis of messy data. Lifetime Learning Pub., Belmont, Calif.

Myers, H.R. 1982. Climatological data of Stillwater, Oklahoma 1893-1980. Oklahoma Agr. Exp. Sta. Res. Rep. P-821.

Ralphs, M., M. Kothmann, and L. Merrill. 1984. Proper stocking for short-duration grazing. Texas Agr. Exp. Sta. Pro. Rep. 4190.

Savory, A. 1978. A holistic approach to ranch management using short duration grazing, p. 555-557. In: D.N. Hyder (ed.) Proc. First Int. Rangeland Congr., Soc. Range Manage., Denver, Colo.

Stuth, J.W., D.R. Kirby, and R.E. Chmielewski. 1981. Effect of herbage allowance on the efficiency of defoliation by the grazing animal. Grass and Forage Sci. 36:9-15.

Tainton, N.M., P. de V. Booysen, and R.C. Nesh. 1977. The grazing rotation: effect of different combinations of presence and absence. Proc. Grassland Soc. South Africa 12:103-104.

Walker, J.W. 1984. Grazing managemnt theories and their application to short duration grazing, p. 176-180. In: Proc. 1984 Forage and Grassland Conf., Amer. Forage and Grassland Council. 